Research Article

\title{
Comparison of Ethanol Extract from Roots, Leaves, and Flowers of Calotropis gigantea as Anticancer on T47D Breast Cancer Cell Lines
}

\author{
Roihatul Muti'ah ${ }^{1, *}$, Sukardiman², Aty Widyawaruyanti2, Siti Zulaikah³ \\ 1Pharmacy Department, Science and Technology Faculty, Islamic State Maulana Malik Ibrahim University, Malang, \\ Indonesia \\ 2Pharmacognosy and Phytochemical Department, Pharmacy Faculty, Airlangga University, Surabaya, Indonesia \\ ${ }^{3}$ Academy of Health Analyst, Malang, Indonesia
}

\section{ARTICLE INFO}

Article history

Received

Revised

Accepted

Available online: 1 October 2016

Author corresponding

Email: roihatulmutiah@gmail.com

\section{ABSTRACT}

This research aims to find out the anticancer activity of ethanol extract from the roots, leaves, and flowers of Calotropis gigantea. This experiment was conducted by MTT method on T47D breast cancer cell line. The result showed that the root of Calotropis gigantea was more cytotoxic $\left(\mathrm{IC}_{50} 89.76 \mu \mathrm{g} / \mathrm{mL}\right)$ on T47D breast cancer cell line than the leaves $\left(I C_{50} 459.51 \mu \mathrm{g} / \mathrm{mL}\right)$ and the flowers $\left(I C_{50}>1000\right)$. Based on the result, roots are potent to be chemotherapeutic agent, especially in breast cancer.

Keywords: anticancer, Calothropis gigantea, , ethanol extract

\section{Introduction}

Cancer or known as malignant neoplasm is the rapid creation of abnormal cells that grow beyond their usual boundaries, and can invade adjoining parts of the body and spread to other organs (metastases). Until now, cancer is still one disease that is the world's problem. It was reported that in 2008 a number of 12.7 cancer cases lead 7.6 million deaths or about $13 \%$ from all people's death caused by cancer (American Science Society, 2015). In USA, cancer was leading that caused of death after cardiovascular disease. It was reported that $1,638,910$ cases of cancer caused 577,190 deaths. In Indonesia, malignant neoplasm is causing of death number 6 after infectious disease, cardiovascular, traffic accident, malnutrition, and genetic disease (Mardisiswojo \& Radjakmangunsudarso, 1968). Breast cancer is one of five kinds of cancers that caused most death in the world, besides lung cancer, stomach, colorectal, and liver. Breast cancer causes 519,000 deaths each year (American Cancer Society, 2015).
Some medical treatments were applied to cure breast cancer. They were surgery, chemotherapy, and radiotherapy. But, these treatments could not treat the disease effectively. Failures that often occur in cancer treatment (mostly in chemotherapy) are caused by low selectivity of chemotherapeutic agent on normal cells and causes serious side effect in the patients. Furthermore, the failure of chemotherapy is also caused by the resistance of cancer cells to chemotherapeutic agents. This resistance phenomenon can impact on increasing therapeutic doses. To overcome these problems are needed medicine that has molecular target specifically and high selectivity on normal cells.

Recently some researches related to the ability of Calotropis gigantea as anticancer agent is cardenolid. The compound was extracted from the leaves that has cytotoxic activity on MCF-7 cancer cells, KB (skin cancer cells) and NCL-H18 (lung cancer cells) (Saeka \& Sutthivaiyakit, S., 2010). Dichloromethane extract from the leaves also has cytotoxic activity on many cancer cells, such as 
MCF-7, MDA-MB-231, HeLa cells, HT-29, SKOV-3, and Hep-G2 (Wong et al., 2011). Calotropon extracted from the roots also has cytotoxic activity on K562 leukaemia cells and 7901 stomach cancer (Wang et al., 2008). Methanol extract and chloroform fraction of the flowers have antitumor activity on mice infected Ascites carcinoma (Habib et al., 2010). But, the data about anticancer activity of the flowers, leaves, branches, and roots to cure T47D breast cancer cell are not known. Moreover, the mechanism of action of anticancer agents from Calotropis gigantea is not known yet. In this research have been conducted a test of ethanol extract from the leaves, flowers, and roots of Calotropis gigantea on T47D breast cancer cells. From this research was obtained data about the effectiveness of anticancer agents to cure breast cancer from each parts of this plant, and the extract is selected by highest effectiveness. Selected extract will be developed to be anticancer drug that effective and selective by the Selective Apoptosis Antineoplastic Drug (SAAND) method. SAAND is a method concerned in mechanism of drug action that is expected to be selective anticancer agent (only destroy cancer cells without destroy normal cells) by mechanism of cell apoptosis.

\section{Materials and methods}

\subsection{Materials}

Calotropis gigantea (roots, leaves, and flowers) was obtained from Malang city, East Java. Solvent for extraction is ethanol $70 \%$. Breast cancer cell, T47D, was obtained from Cancer Chemoprevention Research Centre (CCRC), faculty of Pharmacy, Gajah Mada University. The cell is cultured in Rosewell Park Memorial Institute (RPMI) with some chemicals addition such as 10\% heat-inactivated fetal bovine serum (FBS) (PAA Laboratories), 1\% $\mathrm{v} / \mathrm{v}$ penicillin-streptomycin (Nacalay Tesque), and 1,0 mM L-glutamine (Nacalay Tesque). The cell is cultured in the incubator with $5 \% \mathrm{CO}_{2}, 37^{\circ} \mathrm{C}$. Chemicals for this research are DMSO (Dimethyl sulfoxide) $1 \%$, trypsin $0.025 \%$, phosphate buffer solution (PBS), $\mathrm{HCl}$ (Merck) and MTT (3-(4,5dimetiltiazole-2-il)-2,5-difeniltetrazolium bromide).

\subsection{Plant determination}

Analysis of plant morphology was conducted by Indonesian Institute of Sciences (LIPI), East Java.

\subsection{Sample preparation}

Each part of Calotropis gigantea (roots, leaves, and flowers) was dried under sunlight while it is covered by black cloth. The dried plant was powdered and inserted to the dry brown bottle.

\subsection{Plant extraction}

The sample was extracted by ethanol $70 \%$ with ratio 1:5 for 72 hours. The residue from filtering process was re-extracted by ethanol $70 \%$ with ratio $1: 2$ for 72 hours. Re-maceration process was conducted two times. All filtrate obtained was evaporated by rotary evaporator.

\subsection{Cytotoxic assay}

The human breast cancer T47D cell lines were cultured in 96-well plates (Becton Dickinson Co., NJ., USA), and each well contained $5 \times 10^{3}$ cells. The cell culture was incubated in a humidified incubator at $37^{\circ} \mathrm{C}$ in an atmosphere of $5 \% \mathrm{CO}_{2}$ and $95 \%$ air for 24 hours. Cell confluence or crowding of cells in the plate was about $70-80 \%$. After 24 hours incubation, culture medium was discarded. The cells were treated by Calotropis gigantea extract and fractions (treatment groups) or the vehicle (control group), and then incubated for 24 hours. The concentrations of the fraction were 1, 10, 100, 500 and $1000 \mu \mathrm{g} / \mathrm{mL}$ in DMEM. After incubation, the cells were incubated with 0.5 $\mathrm{mg} / \mathrm{mL}$ MTT for 4 hours in $37^{\circ} \mathrm{C}$. Viable cells react with MTT to produce purple formazan crystals. After 4 hours, the stopper 10\% SDS (Sigma Co., St. Louis, MO) in $0.01 \mathrm{~N} \mathrm{HCl}$ (Merck) was added to dissolve the formazan crystal. The cells were incubated for 24 hours in room temperature and protected from light. After incubation, the cells were shaken, and cells absorbance was measured by ELISA reader at $595 \mathrm{~nm}$.

\subsection{Data analysis}

The experimental data was absorbance of each well, and then converted to percentage of viable cells as described in equation (1).

Percentage of viable cells $=[B-C / A-C] \times 100 \%$

Where $A, B$ and $C$ were absorbance of control group, treatment group and medium, respectively. The potency of cytotoxic effect was represented by $\mathrm{IC}_{50}$ value calculated using probit analysis. 


\section{Result and discussion}

\subsection{Extraction of Calotropis gigantea}

Leave, flower, and root powders of Calotropis gigantea were weight $350 \mathrm{~g}$ and were extracted by ethanol $70 \%$. These extractions produced crude extract with yellowish brown colour and give percentage yield $21.4 \%, 22.6 \%$, and $4.29 \%$ for leaves, flowers and roots, respectively.

\subsection{Anticancer assay of Calotropis gigantea}

Anticancer activity is determined by MTT method. Cancer cell used in this study was T47D breast cancer cells. T47D cells are continuous cell line isolated from the tumour tissue of breast ductal of a 54 woman. Continuous cell line is often used in the in vitro cancer research because it is easy to handle, unlimited replication capabilities, high homogeneity, and easily replaced by frozen stock if it is contaminated.

Each extract of the plant was dissolved by Dimethyl sulfoxide (DMSO) as stock solutions that had been diluted by suitable solvent for concentration needed. DMSO is a good solvent for inorganic and organic ions. At low concentration, DMSO is relatively no effect on cell growth, but on certain concentration, DMSO has significant cytotoxic activity. DMSO 1.25\% used as a solvent on HeLa cell and Radji cell has relatively no effect on cell proliferation.

The cytotoxicity assay using DMSO $2 \%$ on some cell lines does not have effect on cell growth. It was reported that research used DMSO $0.1 \%$ $(\mathrm{v} / \mathrm{v})$ has no correlation the death of T47D cell (Radji et al., 2004). Another research said that DMSO $4 \%$ that does not interfere on cell proliferation of myeloma (Nurrochmad, 2001). In this research, DMSO concentration used was $0.1 \%$ $(\mathrm{v} / \mathrm{v})$. The extract with the highest anticancer activity is selected for further investigation.

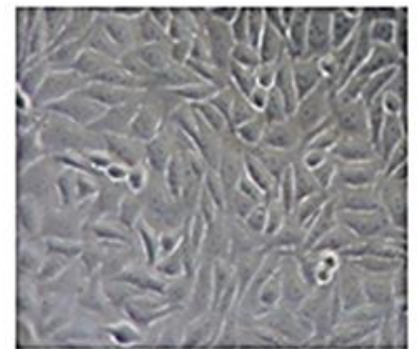

(A) Control cell

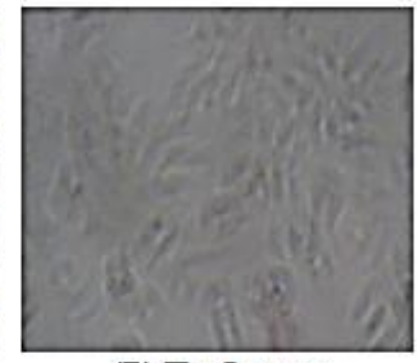

(B) The Leaves

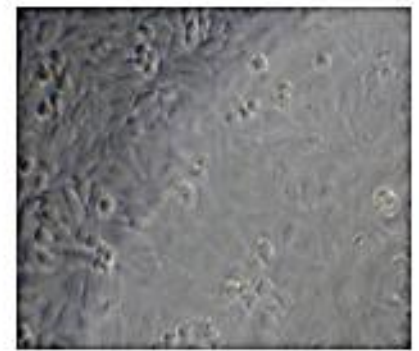

(C) The Flowers

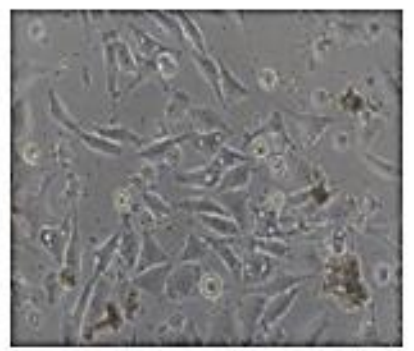

(D) The Root

Fig. 2. Morphology of T47D cell is treated with different parts of Calotropis gigantea. The cell is observed under microscope with 200 time of magnification. The control cells change to form blabbing, swelling and stringy. 


\section{Conclusion}

Ethanol extract from the roots $\left(\mathrm{IC}_{50} 89.76\right.$ $\mu \mathrm{g} / \mathrm{mL}$ ) of Calotropis gigantea has higher cytotoxic potential on the T47D breast cancer cell than ethanol extract from the leaves $\left(\mathrm{IC}_{50} 459.51 \mu \mathrm{g} / \mathrm{mL}\right)$ and the flowers $\left(\mathrm{IC}_{50}>1000\right)$. The roots can be developed to be chemotherapy agent, especially for breast cancer.

\section{References}

Habib, M.R., Aziz, M.A. \& Karim, M.R. (2010). Inhibition of Ehrlich's ascite carcinoma by ethyl acetate extract from the flower of Calotropis gigantea in mice. Journal of Applied Biomedicine, 8(1), 47-54.

Mardisiswojo, S. \& Radjakmangunsudarso, $\mathrm{H}$. (1968). Cabe puyang warisan nenek moyang. Jakarta: PT. Karya Wreda.

Nurrochmad, A. (2001). Sintesis kurkumin, bisdemetoksikurkumin,

bisdemetoksidehidroksikurkumin dan

pentagamavunon-0 serta uji kesitotoksikannya terhadap sel mieloma dan sel mononukleat normal secara in vitro. Tesis, Universitas Gadjah Mada, Yogyakarta.
Radji, M., Surniati, A., \& Indani, N. (2004). Uji mutagenisitas dan anti kanker eksrak aseton dan n-heksana dari kulit batang sesoot (Garcinia pricrorhiza Miq.). Majalah IImu Kefarmasian, 1(2), 69-78.

Saeka, C., \& Sutthivaiyakit, S. (2010). Cytotoxic cardenolides from the leaves of Calotropia gigantea. Chem Pharm Bull (Tokyo), 58(5), 756-758.

Society, A. C. (2015). Global cancer facts \& figures 3rd edition. Atlanta: American Cancer Society, Inc.

Wang, Z.N., Wang, M.Y., Mei, W.L.,Han Z., \& Dai, H.F. (2008). A new cytotoxic pregnanone from Calotropis gigantea. Molecules, 13, 3033-3039.

Wong, S.K., Lim, Y.Y., Abdullah, N.R., \& Nordin, F.J. (2011). Assessment of antiproliferative and antiplasmodial activities of five selected Apocynaceae species. BMC Complementary and Alternative Medicine, 11(1), 3. 